theoretical, but contains just the information which a second-year student wants. The book is well printed, and contains a great many working drawings and diagrams. It is hoped that the author may find time some day to write a companion volume on alternating-current electrical engineering.

L. C.

\section{EDUCATION AND EMPLOYMENT.}

A Handbonk of Employments. Specially Prepared for the Use of Boys and Girls on Entering the Trades, Industries, and Professions. By Mrs. Ogilvie Gordon. Pp. 444. (Aberdeen : Rosemount Press, 1908.) Prire Is, net.

THE system of apprenticeship, which has been so largely instrumental in producing and maintaining the highly skilled workmen for which English industry has always been famed, is slowly but surely dying out. Especially in the large towns, it is more and more difficult to find employers who are willing to take bound apprentices; they complain that such apprentices take ittle interest in their work, are not so willing or anxious to please as boy labourers, and that the high rents they have to pay in towns make their bench room so expensive that in these days of keen competition they cannot afford to take apprentices.

On the other hand, there are so many ways in which boys from fourteen to eighteen can earn comparatively high wages in unskilled employments, that the temptation to their parents to abandon any attempt to apprentice them and to make them immediate wage-earners is very strong.

To endeavour to counteract these tendencies, several local authorities have started some form of industrial or trade school, and although these will never probably take the place of apprenticeship, as the conditions in a school can never be the same as in the shops, they will help to stimulate the interest of the boys in manual pursuits, and so form a strong incentive to learn some trade; and they will also make the trade easier to acquire by the training of eye and hand they have received in the school, as well as by the knowledge they have acquired.

These schools may therefore be expected further to increase and develop, and may become gradually a necessity of our industrial system. But whereas the old apprenticeship system automatically regulated the supply to the demand, any artificial system of drafting boys into given trades will need careful control.

The introduction to Mrs. Gordon's book is most interesting and suggestive; the twenty pages show that the writer has not only given great attention to the problems of employment, but has also been in close touch with them in their most important aspects. Mrs. Gordon strongly urges the formation of employment bureaux to give information as to the local prospects of employment, the remuneration offered and prospects of advancement, the qualifications required for the various occupations, and the facilities offered in technical and continuation classes. It is suggested that these bureaux should be managed by committees, on which the education committee, the town or borough council, chamber of commerce, and association of social workers should be represented. We would suggest the addition of employers of labour. A scheme for such a committee is given, from which it appears that the probable cost of a bureau would be between $150 l$. and $250 l$. per annum. For the reasons given above, in addition to those Mrs. Gordon puts forward, we believe that bureaux on some such lines as these will gradually become a necessary part of our educational system.

The remainder and greater part of the book (some 400 pages) is the result of inquiries undertaken in four of the large cities of Scotland as to the conditions of employment in some seventy-six industrial occupations requiring short periods of training, and more than roo industrial and professional occupations requiring long periods of training. The inquiries were made voluntarily in Glasgow by Mr. R. H. Tawney, an assistant in the Glasgow University, in Edinburgh by Miss Chrystal Macmillan, in Dundee by Mrs. Carlaw Martin, and in Aberdeen by Mrs. Elliot Ogston Clark; and although, necessarily, some of the results are chiefly of local interest, the greater part, with slight modifications of hours and wages, remain true of any district, and the whole forms a most valuable handbook, giving in an easily acressible form the main features of almost every trade and profession.

\section{OUR BOOK SHELF.}

Self-Instruction in the Practice and Theory of Navlgation. By the Earl of Dunraven, Extra Master. Revised and enlarged edition in three vols. Vol. i., pp. xxvii +272 ; vol. ii., pp. ix +337 ; vol. iii., pp. ix +340. (London: Macmillan and Co., Ltd., I908.) Vols. i. and ii., I7s. net; vol. iii., $8 s$. $6 d$. net.

Eight years ago the Earl of Dunraven wrote a work in two volumes on the theory and practice of navigation. It was an extraordinary, but in some respects an excellent book. It was extraordinary in the sense that the author had, as he frankly admitted, no great store of information beyond that necessary to satisfy the nautical examiners of the Board of Trade for an extra master's certificate. But if he made little attempt to probe the theoretical principles upon which the practice of navigation rests, he had mastered very thoroughly that portion of the science into which an examiner might inquire. It was an excellent book, because the author knew how to teach; he had the art of successfully conveying to the pupil just that amount of information which would carry him through the ordeal of examination, and we have no doubt that many who write themselves "Extra Masters" are indebted to Lord Dunraven for this qualification. When the choice of a teacher lies between the man of acknowledged mathematical capacity who cannot teach and the indifferently equipped man who can, it is, for the purposes of examination, better to falt into the hands of the man of moderate acquirements.

But there came a time when the Board of Trade raised their standard. As Lord Dunraven puts it, "the Board of Trade in their infinite wisdom decreed that a master mariner . . . must not only be a pastmaster in the art of navigation, but must also qualify as a naval architect and shipbuilder, be an accurate cartographer, and well advanced in mensuration and

No. 2017 , VOL. 78] 